\title{
PROFIL PERBANDINGAN KARAKTERISTIK LOMPAT VERTIKAL PADA ATLET BULUTANGKIS PRIA DENGAN ATLET BULUTANGKIS WANITA
}

\section{PROFILE COMPARISON OF THE CHARACTERISTICS OF VERTICAL JUMP IN MEN'S BADMINTON ATHLETES WITH WOMEN'S BADMINTON ATHLETES}

\section{Tommy Apriantono ${ }^{*}$, Indria Herman ${ }^{2}$, Rini Syafriani $^{3}$, Widyawardana Adiprawita ${ }^{4}$, Bagus Winata ${ }^{5}$, Agung Dwi Juniarsyah ${ }^{6}$}

1,3,4,5,6 Sekolah Farmasi/Magister Ilmu Keolahragaan, Institut Teknologi Bandung, Ganesha No.10, Lb. Siliwangi, Coblong, Kota Bandung, Jawa Barat, 40132, Indonesia 2Fakultas Teknik Mesin dan Dirgantara/Perancangan Mesin, Institut Teknologi Bandung, Ganesha No.10, Lb. Siliwangi, Coblong, Kota Bandung, Jawa Barat, 40132, Indonesia

\section{*Corresponding Author: Tommy Apriantono, tommy@fa.itb.ac.id}

Received: 2021-09-06; Revised: 2021-12-01; Accepted: 2021-12-01

\begin{abstract}
Abstrak
Tujuan daripada penelitian ini adalah untuk mengukur kemampuan lompat vertikal pada atlet bulutangkis pria dan wanita. Sebanyak 49 atlet yang berusia 18-19 tahun mengikuti kegiatan penelitian ini. Secara lebih spesifik mereka dibagi menjadi 2 kategori, yaitu kategori putra $\mathrm{n}=26$ (tinggi badan $=171.2 \pm 6.91 \mathrm{~cm}$; berat badan $=64.02 \pm 9.67 \mathrm{Kg} ; \mathrm{BMI}=21.89 \pm 2.49 \mathrm{Kg} / \mathrm{m}^{2}$ ), dan kategori putri $\mathrm{n}=23$ (tinggi badan $=159.09 \pm 3.40 \mathrm{~cm}$; berat badan $=56.79 \pm 9.40 \mathrm{Kg}$; BMI $=22.39 \pm$ $3.08 \mathrm{Kg} / \mathrm{m}^{2}$ ). Dalam penelitian observasional ini, seluruh peserta diminta untuk melakukan lompatan vertikal sebanyak dua kali diatas Takei-5414-digital vertical jump meter. Statistical analysis menunjukkan bahwa terdapat perbedaan antara pria dan wanita pada lompatan vertikal dengan kaki kiri ( $\mathrm{p}=0.001)$, lompatan vertikal dengan kaki kanan $(\mathrm{p}=0.001)$, lompatan vertikal dengan kedua kaki $(\mathrm{p}=0.001)$. Kesimpulan penelitian ini memperlihatkan bahwa, atlet laki-laki bulutangkis memiliki kemampuan lompatan yang lebih baik dibandingkan dengan atlet bulutangkis wanita.
\end{abstract}

Kata Kunci: bulutangkis, ledakan otot, power, performa

\begin{abstract}
The purpose of this study was to measure the vertical jump ability of male and female badminton athletes. A total of 49 badminton athletes aged 18-19 years participated in this study. More specifically they were divided into 2 categories, namely the male category $n=26$ (height $=171.2 \pm 6.91 \mathrm{~cm}$; weight $=$ $64.02 \pm 9.67 \mathrm{Kg} ; \mathrm{BMI}=21.89 \pm 2.49 \mathrm{Kg} / \mathrm{m} 2$ ), and the female category $n=23$ (height). body $=159.09 \pm 3.40$ $\mathrm{cm}$; body weight $=56.79 \pm 9.40 \mathrm{Kg} ; \mathrm{BMI}=22.39 \pm 3.08 \mathrm{Kg} / \mathrm{m} 2$ ). All participants were asked to do two vertical jumps on the Takei-5414-digital vertical jump meter. Statistical analysis showed that there were differences between men and women in vertical jumps with the left foot $(p=0.03)$, vertical jumps with the right foot $(p=0.02)$, vertical jumps with both feet $(p=0.001)$. This study shows that male badminton athletes have a better jumping ability than female badminton athletes.
\end{abstract}

Keyword: badminton, explosive movement, power, performance

How To Cite: Apriantono, T., Herman, I., Syafriani, R., Adiprawita, W., Winata, B., Juniarsyah, A.D. (2021). Perbandingan karakteristik lompat vertikal pada atlet bulutangkis pria dengan atlet bulutangkis wanita, 4 (1), 10-18. doi:http://dx.doi.org/10.31258/jope.4.2.10-18

Journal Of Sport Education (JOPE) is an open access article under the CC-BY-SA 4.0 


\section{PENDAHULUAN}

Sebagai negara dengan jumlah populasi penduduk sebanyak 266,91 juta jiwa dan berada di peringkat keempat negara berpenduduk terbanyak di dunia (Kurniawati \& Sugiyanto, 2021) bulutangkis merupakan salah satu olahraga yang di gemari oleh masyarakat Indonesia. Fakta tersebut didasarkan pada catatan gemilang yang telah diraih oleh Indonesia dalam beberapa ajang Internasional yang telah diikuti. Tercatat, pada Olimpiade 1992 di Barcelona, dimana pada saat itu bulutangkis untuk pertama kalinya diresmikan sebagai cabang olahraga yang dipertandingkan dalam Olimpiade, Indonesia berhasil mendapatkan dua medali emas pertamanya dalam cabang bulutangkis, masing-masing di kategori tunggal putri yang diwakili oleh Susi Susanti dan dikategori tunggal putra yang diwakili oleh Alan Budikusuma. Catatan akan prestasi gemilang tersebut yang menjadi dasar terbentuknya euphoria dan kecintaan terhadap bulutangkis, sehingga dapat tumbuh dan berkembang di masyarakat Indonesia sampai saat ini (Arisman, Saripin, 2017; Juang, 2015; Syahruddin, Imam, Lungit, Ramdan, \& Bagus, 2019; Syaifudin, 2013).

Fakta lain mengatakan bahwa, dalam perjalanan panjang sejarah bulutangkis Indonesia pada ajang Olimpiade, khususnya dalam rentang waktu dari Olimpiade 1992 di Barcelona sampai dengan Olimpiade 2016 di Rio de Janerio Brazil, Indonesia terlihat inkonsisten dalam mempertahankan tradisi mendapatkan emas pada ajang tersebut. Hal ini didasarkan dengan fakta bahwa Indonesia sempat absen dalam mendapatkan medali emas pada olimpiade di 2012 (London). Medali emas baru kembali dirasakan pada tahun 2016, dimana ketika itu pasangan ganda campuran Indonesia yang diwakili oleh Tontowi Ahmad dan Lilyana Natsir yang meraih medali emas setelah mengalahkan ganda campuran Malaysia Chan Peng Soon dan Goh Liu Ying (Setiawan, Effendi, \& Toha, 2020; Ulil, Pratomo, \& Subiyono, 2013).

Di sisi lain, bulutangkis merupakan olahraga non-contact yang digemari di Indonesia (Apriantono, Herman, Winata, Hidayat, et al., 2020). Tercatat, semenjak diresmikan pada Olimpiade Barcelona tahun 1992, bulutangkis menjadi salah satu olahraga yang diminati oleh rakyat Indonesia, sekaligus menjadi salah satu cabang olahraga unggulan yang dimiliki Indonesia untuk meraih medali di setiap kompetisi/perhelatan olahraga Internasional (Apriantono, Herman, Winata, Hidayat, et al., 2020). Secara lebih spesifik, fakta terkait keberhasilan atlet-atlet Indonesia dalam mengharumkan nama baik Indonesia pada Olimpiade Barcelona tersebut, adalah faktor utama yang membuat bulutangkis menjadi olahraga yang digemari masyarakat di Indonesia (Apriantono, Herman, Winata, Hidayat, et al., 2020).

Sejalan dengan popularitas bulutangkis yang semakin berkembang saat ini, penelitian pada bulutangkis pun mengalami banyak perkembangan, terlebih penelitian pada area fisiologi bulutangkis. Pada umumnya para peneliti meneliti bagaimana karakteristik fisiologi atlet bulutangkis guna menentukan desai pelatihan yang tepat bagi mereka (Alcock \& Cable, 2009; Arisman, Saripin, 2017; Cabello Manrique \& González-Badillo, 2003; Cece, 2020; Deka, Berg, Harder, Batelaan, \& McGRATH, 2017; Rampichini et al., 2018). Sebagai contoh salah satu penelitian, yaitu, Oliver Faude et al. (Faude et al., 2007) meneliti tentang karakteristik fisiologi atlet bulutangkis, dan memberikan kesimpulan bahwa bulutangkis adalah olahraga explosive movement, dengan karakteristik intermittent, yang membutuhkan kebutuhan aerobic dan anaerobic untuk menunjang performa setiap atlet dalam setiap pertandingan. Di sisi lain, penelitian yang dilakukan oleh Apriantono et al. (Apriantono, Herman, Winata, Hidayat, et al., 2020) menegaskan bahwa bulutangkis merupakan olahraga non-contact dengan intensitas tinggi dan rendah, dan diselingi dengan periode pemulihan pemulihan (intermittent).

Berdasarkan beberapa literasi sebelumnya yang telah mengukur dan meneliti karakteristik bulutangkis, dapat disimpulkan bahwa setiap gerakan bulutangkis adalah 
gerakan explosive movement yang dilakukan secara intermittent dalam suatu pertandingan bulutangkis (Phomsoupha \& Laffaye, 2015; Zhang, Li, \& Jiang, 2013). Salah satu gerakan yang sering dilakukan berulang-ulang adalah lompatan, dimana lompatan sering dilakukan untuk melakukan pukulan smash (Lee \& Loh, 2019). Pukulan smash dengan tekhnik meloncat, merupakan salah satu gerakan yang dilakukan untuk bertujuan memberikan shuttlecock yang memiliki kecepatan tinggi, sehingga lawan tidak dapat mengembalikan shuttlecock tersebut, dan menjadi point keuntungan bagi atlet yang melakukan smash tersebut (Faccini \& Dal Monte, 1996).

Lompatan pada bulutangkis merupakan gerakan explosive movement, yang memiliki kaitan erat dengan cedera patellar tendinopathy, berdasarkan hal tersebut, banyak sekali para pelatih dan atlet sangat memfokuskan latihan lompatan guna mendukung performa mereka, dan menghindarkan mereka dari resiko terkenanya suatu cedera (Pardiwala, Subbiah, Rao, \& Modi, 2020). Namun, sayangnya penelitian tentang sejauh apa karakteristik lompatan pada atlet bulutangkis sangat jarang dilakukan, sehingga para pelatih tidak memiliki gambaran yang jelas untuk membuat desain pelatihan yang tepat bagi para atlet. Hal ini berbanding terbalik dengan cabang olahraga bola volley yang sudah mengukur karakteristik lompatan setiap atlet berdasarkan jenis kelamin, ataupun level bermain, sehinga mereka memiliki gambaran terkait desain pelatihan yang tepat bagi atlet bola volley (Ral, Evri, \& An, 2006). Oleh sebab itu, tujuan daripada penelitian ini adalah untuk mengukur kemampuan lompat vertikal pada atlet bulutangkis pria dan wanita, sehingga menggunakan temuan tersebut sebagai dasaran kuantitatif yang digunakan pelatih untuk mendesain suatu pelatihan yang tepat bagi atlet bulutangkis. Kami memiliki hipotesis bahwa atlet bulutangkis pria akan memiliki lompatan vertikal yang lebih baik daripada atlet perempuan.

\section{METODE}

Penelitian ini merupakan penelitian observasional, yang bertujuan untuk mengetahui hubungan sebab akibat antara dua variabel secara observasional, dimana bentuk hubungan dapat: perbedaan, dan hubungan atau pengaruh. Penelitian ini menilai karakteristik fisiologi atlet, yaitu dengan membandingkan pengukuran uji lompat vertikal, yang terdiri dari tiga jenis lompat vertikal, yaitu lompat vertikal dengan kaki kanan, kaki kiri, dan kedua kaki. Penelitian ini penting adanya guna dapat dijadikan temuan baru maupun temuan tambahan yang menguatkan daripada referensi penelitian sebelumnya.

Total 49 atlet badminton usia 18-19 tahun berpartisipasi dalam penelitian ini. Secara lebih spesifik mereka dibagi menjadi 2 kategori, yaitu kategori putra $\mathrm{n}=26$ (tinggi badan $=$ $171.2 \pm 6.91 \mathrm{~cm}$; berat badan $=64.02 \pm 9.67 \mathrm{Kg}$; BMI $=21.89 \pm 2.49 \mathrm{Kg} / \mathrm{m}^{2}$ ), dan kategori putri $\mathrm{n}=23$ (tinggi badan $=159.09 \pm 3.40 \mathrm{~cm}$; berat badan $=56.79 \pm 9.40 \mathrm{Kg} ; \mathrm{BMI}=22.39 \pm 3.08$ $\mathrm{Kg} / \mathrm{m}^{2}$ ). Seluruh sample diambil berdasarkan kriteria inklusi dan eksklusi. Adapun kriteria inklusi pada penelitian ini adalah: (1) Subjek penelitian berasal dari klub bulutangkis dengan peringkat 3 besar yang telah ditetapkan oleh PBSI (Persatuan Bulutangkis Seluruh Indonesia). (2) Subjek penelitian adalah atlet bulutangkis yang berusia 16 tahun, dan merupakan atlet pilihan dari pemandu bakat PB Jaya Raya Jakarta, (3). Subjek penelitian adalah atlet yang minimal berlatih 15 jam dalam satu minggu. (4). Subjek penelitian merupakan atlet bulutangkis yang pernah mengikuti turnamen tingkat nasional maupun internasional. Sedangkan kriteria eksklusi dalam penelitian ini adalah (1). Atlet yang memiliki riwayat penyakit kardiorespiratori ataupun sakit fisik lainnya, yang dibuktikan dengan pemeriksaan kesehatan. (2). Atlet dengan riwayat merokok.

Dalam penelitian ini mengkaji tentang hubungan karakteristik fisiologi lompatan vertikal kaki kanan, kaki kiri, dan kedua kaki. Dimana ketiga variable tersebut akan dikaitkan dan dianalisis secara deskriptif kuantitatif untuk menentukan perbedaannya, sehingga dapat 
merekomendasikan desain latihan bagi atlet bulutangkis.

Dalam penelitian ini, proses pengambilan data uji lapangan diadakan di Gelanggang Olahraga (GOR) bulutangkis di Bintaro, Tanggerang. Waktu yang dijalankan dalam penelitian ini dalam rentang waktu di bulan Februari sampai dengan Maret 2019, dimana dalam rentang waktu tersebut, seluruh atlet sedang tidak mengikuti pertandingan apapun, dan hanya fokus terhadap proses pelatihan yang diberikan oleh tim pelatih.

Seluruh peserta mendapatkan penjelasan terkait resiko dan manfaat dalam penelitian ini, dan mereka diminta kesediaanya untuk mengisi informed consent sebagai tanda kesediaan mereka mengikuti penelitian ini. Penelitian ini telah lulus uji komite etik yang dikeluarkan oleh komite etik POLTEKKES Bandung (No. 06/KEPK/EC/III/2021). Seluruh peserta melakukan lompatan vertical jump diatas Takei-5414-digital vertical jump meter. Seluruh peserta melakukan lompatan dengan 3 jenis gerakan lompatan vertikal dengan kaki kanan, lompatan vertikal dengan kaki kiri, dan lompatan vertikal dengan kedua kaki. Seluruh peserta diberikan dua kali kesempatan percobaan, dan hasil terbaik diambil dalam penelitian ini.

Seluruh peserta melakukan pemanasan baik secara statis ataupun dinamis selama 5 menit. Setelah melakukan pemanasan, seluruh peserta diminta untuk melakukan lompatan vertikal sebanyak dua kali diatas Takei-5414-digital vertical jump meter. Seluruh peserta melakukan tiga jenis gerakan, yaitu lompatan vertikal dengan kaki kanan, lompatan vertikal dengan kaki kiri, dan lompatan vertikal dengan kedua kaki. Skor ketinggian lompatan vertikal akan langsung secara automatis muncul dalam layer digital Takei. Satu orang administrator akan mencatat hasil tersebut, dan hasil yang paling maksimal akan digunakan sebagai hasil analisis data. Shapiro-Wilk test digunakan untuk menguji distribusi normal pada seluruh data penelitian ini. Sedangkan independent t-test digunakan untuk melihat perbedaan seluruh lompat vertikal antara laki-laki dan perempuan. Taraf signifikansi diterima pada taraf $p<0.05$. Desain penelitian dapat dilihat pada Gambar 1

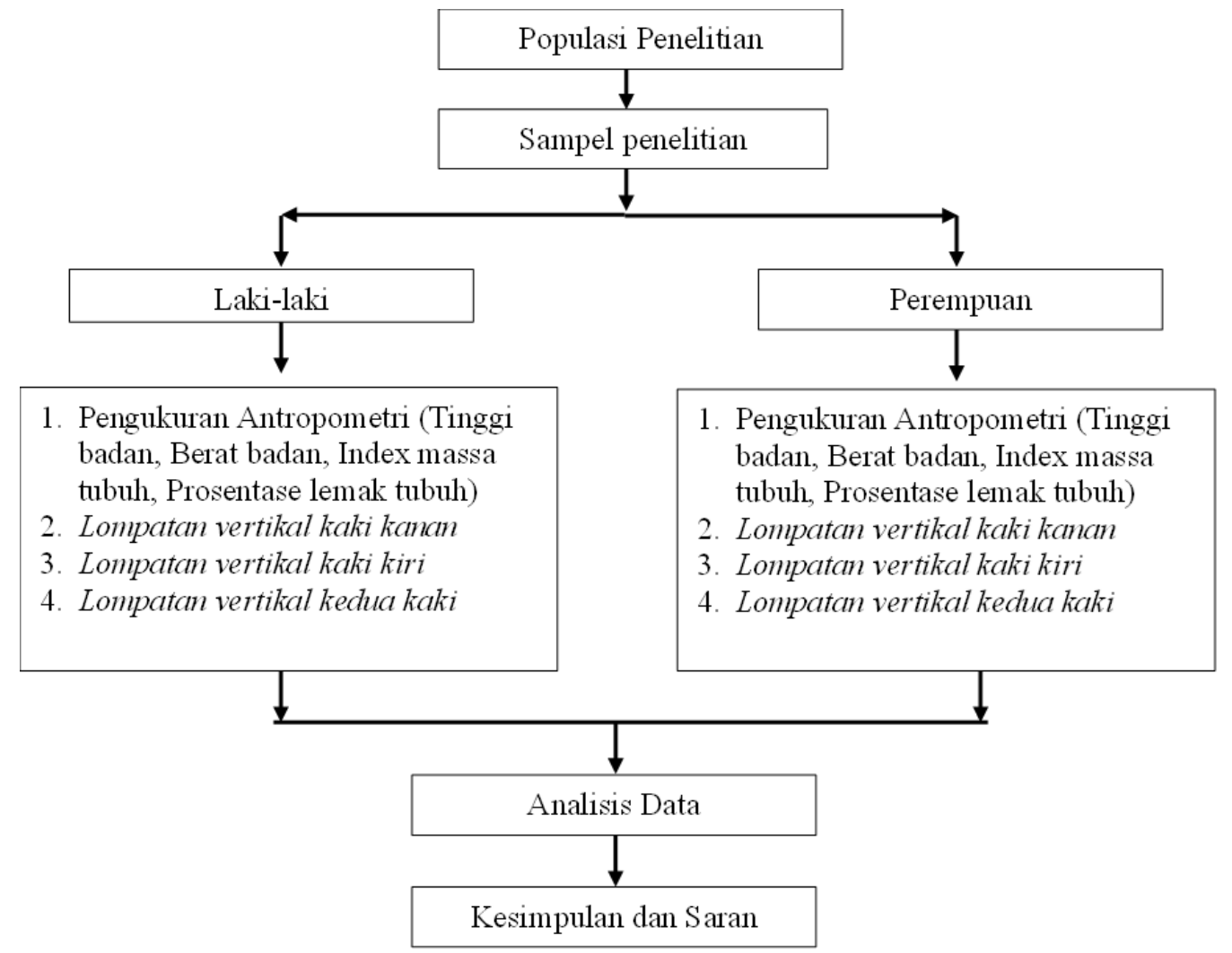

Gambar 1. Desain penelitian

Copyright (c) The Author (s) 2021

ISSN 2654-4474 (Print), ISSN 2654-9069 (Online) 
Journal of Sport Education (JOPE), volume (nomor) tahun - 14

Tommy Apriantono ${ }^{1 *}$, Indria Herman ${ }^{2}$, Rini Syafriani ${ }^{3}$, Widyawardana Adiprawita ${ }^{4}$, Bagus Winata ${ }^{5}$, Agung Dwi Juniarsyah $^{6}$

\section{HASIL}

Analisis statistik menunjukkan bahwa terdapat perbedaan antara pria dan wanita pada lompatan vertikal dengan kaki kiri $(p=0.001)$, lompatan vertikal dengan kaki kanan $(p=$ $0.001)$, lompatan vertikal dengan kedua kaki $(p=0.001)$. Dapat dilihat pada Tabel. 1 dan Gambar 2.
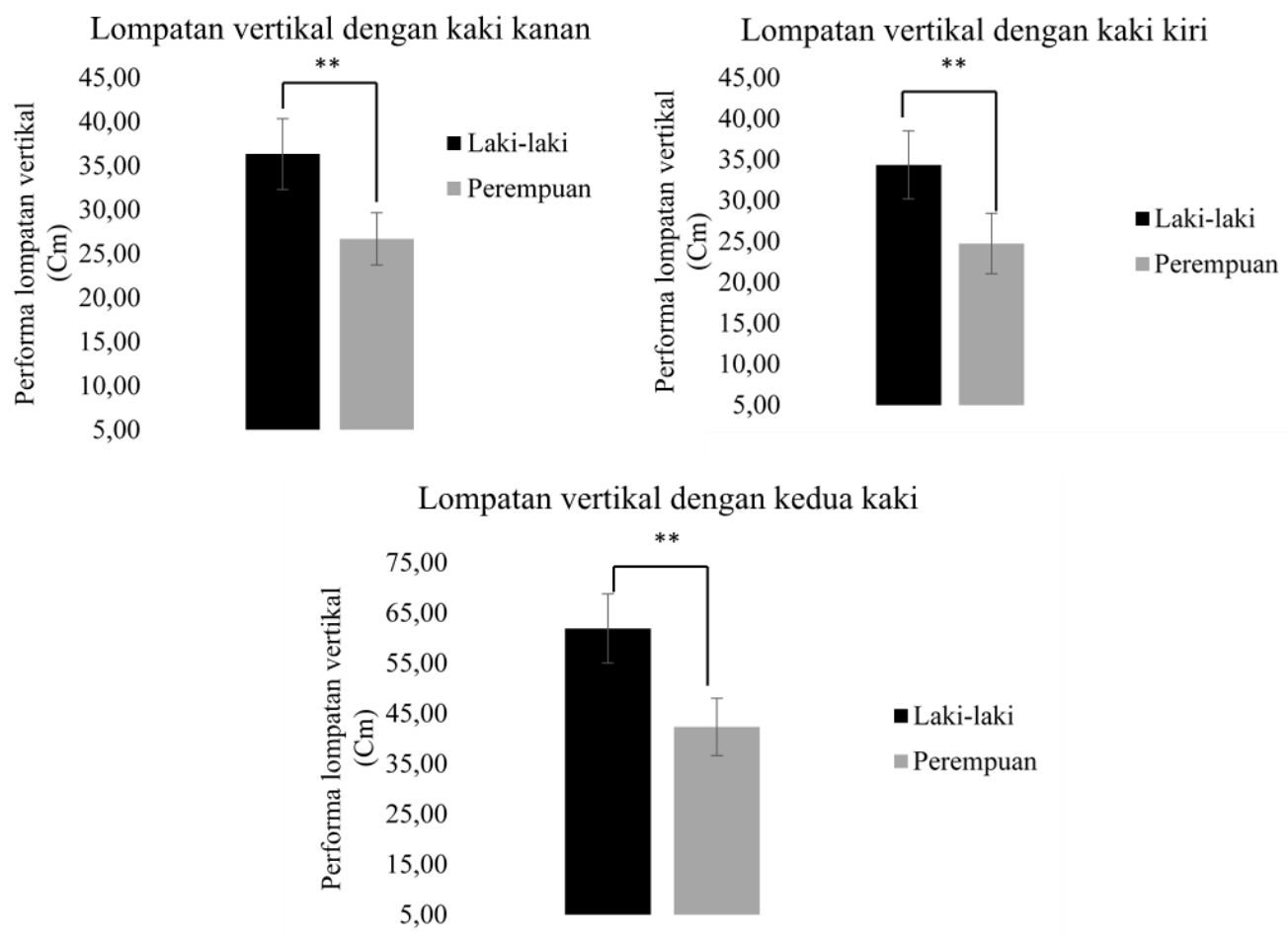

Gambar 2. Grafik perbandingan lompat vertikal antara laki-laki dengan perempuan Keterangan: * Taraf signifikansi $<0.05$.

Tabel 1. Perbandingan lompat vertikal antara laki-laki dengan perempuan

\begin{tabular}{lccc}
\hline \multicolumn{1}{c}{ Variabel } & Laki-laki & Perempuan & Taraf signifikansi \\
\hline $\begin{array}{l}\text { Lompatan vertikal dengan } \\
\text { kaki kanan }\end{array}$ & $36.35 \pm 4.02$ & $26.70 \pm 2.96$ & $0.05^{*}$ \\
$\begin{array}{l}\text { Lompatan vertikal dengan } \\
\text { kaki kiri }\end{array}$ & $34.35 \pm 4.15$ & $24.74 \pm 3.70$ & $0.05^{*}$ \\
$\begin{array}{l}\text { Lompatan vertikal dengan } \\
\text { kedua kaki }\end{array}$ & $61.88 \pm 6.88$ & $42.35 \pm 5.69$ & $0.05^{*}$ \\
\hline
\end{tabular}

\section{PEMBAHASAN}

Penelitian ini bertujuan untuk mengukur kemampuan lompat vertikal pada atlet bulutangkis pria dan wanita, sehingga menggunakan temuan tersebut sebagai dasar kuantitatif yang digunakan pelatih untuk mendesain suatu pelatihan yang tepat bagi atlet bulutangkis. Sesuai dengan hipotesis kami, bahwa atlet bulutangkis pria akan memiliki lompatan vertikal yang lebih baik daripada atlet wanita. Secara lebih spesifik, temuan dalam penelitian ini, menerangkan tiga temuan besar, yaitu: (1) Atlet laki-laki memiliki lompatan vertikal yang lebih tinggi pada lompatan vertikal dengan kaki kanan, (2) Atlet laki-laki memiliki lompatan vertikal yang lebih tinggi pada lompatan vertikal dengan kaki kiri, dan (3) Atlet laki-laki memiliki lompatan vertikal yang lebih tinggi pada lompatan vertikal dengan 
kedua kaki.

Seperti yang telah kita ketahui, bahwa lompatan vertikal pada atlet bulutangkis sangatlah penting, hal ini mengingat lompatabn vertikal menjadi salah satu gerakan vital dalam suatu pertandingan. Hal ini telah dibuktikan oleh beberapa penelitian sebelumnya, yang menganalisis tentang bagaimana lompatan vertikal menjadi suatu gerakan yang paling mendominasi dalam suatu pertandingan bulutangkis. Apriantono., dkk mengungkapkan bahwa dalam suatu pertandingan bulutangkis, didapatkan sebanyak 168 smash shot dalam satu pertandingan, dengan karakteristik smash shot yang menggunkan teknik loncatan (Apriantono, Herman, Winata, \& Hasan, 2020). Oleh karena penelitian tersebut, maka dapat disimpulkan bahwa lompatan vertikal adalah gerakan yang menopang untuk melakukan smash shot, sehingga diharapkan akan menciptakan suatu smash shot yang baik, sehingga dapat mengambil keuntungan angka point dari tekhnkik bermain tersebut.

Penelitian ini mendukung beberapa penelitian sebelumnya yang telah melakukan observasi lompatan vertikal (Ali Rozikin, 2015; Ral et al., 2006). Meskipun kami menyadari bahwa masih sulit ditemukan penelitian yang melakukan observasi tentang lompatan vertikal pada bulutangkis, namun penelitian ini telah mendukung penelitian lompatan vertikal pada cabang olahraga bola voli, yang telah dilakukan oleh Ral et al. (Ral et al., 2006) Dalam temuan penelitian tersebut, Ral et al (Ral et al., 2006) mengungkapkan bahwa atlet laki-laki bola voli memiliki lompatan yang lebih tinggi dibandingkan dengan atlet perempuan. Secara lebih spesifik, atlet laki-laki memiliki performa lompatan vertikal countermovement jump dengan menggunakan bantuan ayunan tangan ( $44.0 \mathrm{vs} 30.86 \mathrm{~cm}$ ). Hal ini sejalan dengan penelitian yang kami lakukan dimana, laki laki selalu mendominasi lompatan vertikal dibandingkan atlet perempuan (36.35 vs $26.70 ; 34.45$ vs $24.74 ; 61.88$ vs 42.35$)$.

Meskipun kami menyadari bahwa penelitian sebelumnya memiliki perbedaan karakteristik kecabangan, namun kami menemukan suatu kesamaan dimana, lompatan yang dilakukan dalam observasi sebelumnya tersebut sama-sama memiliki persamaan, yaitu menggunakan bantuan ayunan tangan dalam melakukan lompatan vertikal. Lompatan vertikal dengan menggunakan ayunan tangan memang dapat membantu setiap peserta untuk menghasilkan lompatan yang semaksimal mungkin (Ali Rozikin, 2015; Harry, Lanier, Nunley, \& Blinch, 2019). Hal ini didukung dengan prinsip biomechanical, dimana otot bahu secara langsung memiliki peran besar atas sepertiga dari kinerja peningkatan lompatan vertikal dengan menggunakan ayunan lengan (Vanezis \& Lees, 2005). Hal ini dianggap wajar, mengingat penelitian lainnya mengatakan bahwa, dengan ayunan lengan tersebut, dapat menitik beratkan tumpuan pada shoulder sehingga menciptakan atau merangsang cadangan power, dan meningkatkan lompatan vertikal pada setiap peserta (Setiawan et al., 2020; Yang et al., 2018).

Literasi lain, yang mendukung bahwa performa laki-laki lebih mendominasi daripada perempuan adalah, adanya perbedaan jenis otot antara laki-laki dan perempuan. Secara lebih spesik, Herbst et al. (Herbst \& Bhasin, 2004) mengatakan bahwa adanya hormone testosterone yang lebih dominan pada pria akan membuat perkembangan hipertrofi otot rangka menjadi lebih signifikan dibandingkan dengan wanita. Perkembangan yang signifikan ini membuat perubahan pada peningkatan kekuatan otot dan kekuatan kaki pada atlet tersebut. Berdasarkan hal tersebut, kami berasumsi bahwa perbedaan signifikansi performa lompatan vertikal antara laki-laki dan wanita sangat dipengaruhi oleh kekuatan otot yang dimiliki, dimana atlet laki-laki memiliki kemampuan otot dan kekuatan kaki yang lebih kuat dibandingkan dengan atlet wanita.

Pada kesimpulannya, penelitian ini menunjukkan secara kuantitatif perbedaan antara performa lompatan vertikal atlet laki-laki bulutangkis dan atlet perempuan bulutangkis, dimana atlet laki-laki bulutangkis memiliki kemampuan lompatan yang lebih baik 
dibandingkan dengan atlet bulutangkis wanita. Di sisi lain, meskipun kami menyadari bahwa terdapat beberapa kekurangan (limitation) dalam penelitian ini seperti: (1) Pentingnya klasifikasi antara level bermain yang lebih spesifik dalam setiap pengukuran lompat vertikal, (2) Adanya faktor siklus circardian, yang harus diperhitungkan, yang memungkinkan terjadinya perbedaan suatu hasil, dan (3) Adanya faktor psikology yang mungkin saja dapat mempengaruhi hasil akhir lompatan, namun temuan dalam penelitian ini kami yakini dapat menambah kekayaan ilmu pengetahuan atau literasi sebelumnya terkait penelitian pada bulutangkis, sehingga dapat digunakan oleh para pelatih, atlet, ataupun peneliti olahraga lainnya untuk meningkatkan performa atlet bulutangkis berdasarkan landasan atau kajian sports science, yang dibuktikan secara kuantitaif ataupun kualitatif.

\section{SIMPULAN}

Penelitian ini menunjukkan bahwa atlet laki-laki bulutangkis memiliki kemampuan lompatan yang lebih baik dibandingkan dengan atlet bulutangkis wanita. Berdasarkan hal tersebut, kami mendorong para pelatih bulutangkis untuk mendesain latihan yang sesuai berdasarkan karakteristik jenis kelamin, dan kemampuan otot, khususnya desain pelatihan kekuatan otot tungkai. Secara lebih spesifik, kami mendorong para pelatih untuk lebih memperhatikan kemampuan lompatan vertikal pada atlet perempuan, sehingga atlet perempuan dapat memiliki performa lompatan yang dapat lebih baik.

\section{DAFTAR PUSTAKA}

Alcock, A., \& Cable, N. T. (2009). A comparison of singles and doubles badminton: heart rate response, player profiles and game characteristics. International Journal of Performance Analysis in Sport, 9(2), 228-237. https://doi.org/10.1080/24748668.2009.11868479

Ali Rozikin, T. H. (2015). Hubungan fleksibilitas dan kekuatan otot tungkai terhadap hasil tendangan eolgol dollyo-chagi pada olahraga taekwondo. JSSF Uournal of Sport Science and Fitness), 4(1), 32-36.

Apriantono, T., Herman, I., Winata, B., \& Hasan, M. F. (2020). Differences of physiological characteristics of taekwondo junior players vs pencak silat junior players, 8(2), 9-15. https://doi.org/10.16926/par.2020.08.15

Apriantono, T., Herman, I., Winata, B., Hidayat, I. I., Hasan, M. F., Juniarsyah, A. D., \& Ihsani, S. I. (2020). Physiological characteristics of Indonesian junior badminton players: Men's double category. International Journal of Human Movement and Sports Sciences, 8(6), 444-454. https://doi.org/10.13189/saj.2020.080617

Arisman, Saripin, A. V. (2017). Hubungan kelentukan pergelangan tangan dan power otot lengan bahu dengan hasil akurasi smash bulutangkis putra pada pb. Angkasa pekanbaru. Journal of Sport Education, 300, 1-10.

Cabello Manrique, D., \& González-Badillo, J. J. (2003). Analysis of the characteristics of competitive badminton. British Journal of Sports Medicine, 37(1), 62-66. https://doi.org/10.1136/bjsm.37.1.62

Cece, V. (2020). Mental training program in racket sports: A systematic review. International Journal of Racket Sports Science, 2(1), 55-71. https://doi.org/10.30827/digibug.63721 
Deka, P., Berg, K., Harder, J., Batelaan, H., \& McGRATH, M. (2017). Oxygen cost and physiological responses of recreational badminton match play. Journal of Sports Medicine and Physical Fitness, 57(6), 760-765. https://doi.org/10.23736/S0022-4707.16.06319-2

Faccini, P., \& Dal Monte, A. (1996). Physiologic demands of badminton match play. American Journal of Sports Medicine, 24(SUPPL.), 64-66. https://doi.org/10.1177/036354659602406s19

Faude, O., Meyer, T., Rosenberger, F., Fries, M., Huber, G., \& Kindermann, W. (2007). Physiological characteristics of badminton match play. European Journal of Applied Physiology, 100(4), 479-485. https://doi.org/10.1007/s00421-007-0441-8

Harry, J. R., Lanier, R., Nunley, B., \& Blinch, J. (2019). Focus of attention effects on lower extremity biomechanics during vertical jump landings. Human Movement Science, 68(September), 102521. https://doi.org/10.1016/j.humov.2019.102521

Herbst, K. L., \& Bhasin, S. (2004). Testosterone action on skeletal muscle. Current Opinion in Clinical Nutrition and Metabolic Care, 7(3), 271-277. https://doi.org/10.1097/00075197-200405000-00006

Juang, B. R. (2015). Analisis kelebihan dan kelemahan keterampilan teknik bermain bulutangkis pada pemain tunggal putra terbaik indonesia tahun 2014. Jurnal Kesehatan Olahraga, 3(1), 109-117.

Kurniawati, E., \& Sugiyanto, C. (2021). Pengaruh struktur umur penduduk terhadap pertumbuhan ekonomi di indonesia. Jurnal Ekonomi Dan Pembangunan Indonesia, 21(1), 41-58.

Lee, J. J. J., \& Loh, W. P. (2019). A state-of-the-art review on badminton lunge attributes. Computers in Biology and Medicine, 108(April), 213-222. https://doi.org/10.1016/j.compbiomed.2019.04.003

Pardiwala, D. N., Subbiah, K., Rao, N., \& Modi, R. (2020). Badminton injuries in elite athletes: a review of epidemiology and biomechanics. Indian Journal of Orthopaedics, 54(3), 237245. https://doi.org/10.1007/s43465-020-00054-1

Phomsoupha, M., \& Laffaye, G. (2015). The science of badminton: game characteristics, anthropometry, physiology, visual fitness and biomechanics. Sports Medicine, 45(4), 473495. https://doi.org/10.1007/s40279-014-0287-2

Ral, a Y. O., Evri, D., \& An, D. I. (2006). Vertical jump performance of professional male and female volleyball players: effects of playing position and competition level, 20(3), 572578.

Rampichini, S., Limonta, E., Pugliese, L., Cè, E., Bisconti, A. V., Gianfelici, A., ... Esposito, F. (2018). Heart rate and pulmonary oxygen uptake response in professional badminton players: comparison between on-court game simulation and laboratory exercise testing. European Journal of Applied Physiology, 118(11), 2339-2347. https://doi.org/10.1007/s00421-018-3960-6 
Setiawan, A., Effendi, F., \& Toha, M. (2020). Akurasi smash forehand bulutangkis dikaitkan dengan kekuatan otot lengan dan koordinasi mata-tangan. Jurnal MAENPO: Jurnal Pendidikan Jasmani Kesehatan Dan Rekreasi, $10(1), \quad 50$. https://doi.org/10.35194/jm.v10i1.949

Syahruddin, S., Imam, I. S., Lungit, L., Ramdan, R. P., \& Bagus, B. W. (2019). Infrared sensor technology (ist) test as a tool for assessment of flexibility. Postepy Rehabilitacji, 33(3), 59. https://doi.org/10.5114/areh.2019.87743

Syaifudin, M. (2013). Olahraga bulutangkis sebagai solusi mengurangi frustasi bagi kalangan pengusaha di yayasan lkk ngesti rahayu sidoarjo. Unesa, 2, 1-4. Retrieved from https://jurnalmahasiswa.unesa.ac.id/index.php/jurnal-kesehatanolahraga/article/view/2463

Ulil, A., Pratomo, D., \& Subiyono, H. S. (2013). Perbedaan hasil latihan umpan balik lob langsung dan lob tak langsung terhadap ketepatan lob dalam olahraga bulutangkis di pb tugu muda kota semarang. Journal of Sport Sciences and Fitness, 2(1), 1-5.

Vanezis, A., \& Lees, A. (2005). A biomechanical analysis of good and poor performers of the vertical jump. Ergonomics, 48(11-14), 1594-1603. https://doi.org/10.1080/00140130500101262

Yang, C., Yao, W., Garrett, W. E., Givens, D. L., Hacke, J., Liu, H., \& Yu, B. (2018). Effects of an intervention program on lower extremity biomechanics in stop-jump and side-cutting tasks. American Journal of Sports Medicine, 46(12), 3014-3022. https://doi.org/10.1177/0363546518793393

Zhang, B., Li, F., \& Jiang, W. (2013). Mixed doubles match technical and tactical analysis of world badminton champion based on mathematical statistics. Advances in Physical Education, 03(04), 154-157. https://doi.org/10.4236/ape.2013.34025 